\title{
Antibacterial Activity of Biosynthesized Ferric Oxide Nanoparticles Using Cissus Quadrangularis Extract
}

Sankareswari Anandam ( $\square$ sankareswari@vvvcollege.org)

Department of Physics, V.V.Vanniaperumal College for Women, Virudhunagar

K. Indira

VVVanniaperumal College for Women

Research Article

Keywords: Fe2O3 nanoparticles, Cissus Quadrangularis, Antibacterial activity

Posted Date: July 20th, 2021

DOI: https://doi.org/10.21203/rs.3.rs-688128/v1

License: (c) (1) This work is licensed under a Creative Commons Attribution 4.0 International License.

Read Full License 


\title{
Antibacterial Activity of Biosynthesized Ferric Oxide Nanoparticles
} using Cissus Quadrangularis Extract

\author{
M.Sankareswari ${ }^{1 *}$ and Ms.K.Indira ${ }^{2}$
}

${ }^{1}$ Department of Physics, V.V.Vanniaperumal College for Women, Virudhunagar

${ }^{2}$ Department of Biotechnology, V.V.Vanniaperumal College for Women, Virudhunagar

Tamilnadu, India.

sankareswari@vvvcollege.org

\begin{abstract}
Green chemistry plays a significant role in protecting and improving the global environment. Green chemistry is a process in which a reducing agent usually a chemical is replaced by an extract of a natural product such as stems, leaves, fruits and its peels etc., of plants for the synthesis of nanoparticles. The metal and metal oxide nanoparticles produced from a plant extract are usually stable for a period of time. The present research work focuses on the synthesis of iron oxide $\left[\mathrm{Fe}_{2} \mathrm{O}_{3}\right]$ nanoparticles using Cissus Quadrangularis commonly known as veldt grape (pirandai in Tamil) plant extract by precipitation method.

The structural, surface morphological and optical properties of the synthesized $\mathrm{Fe}_{2} \mathrm{O}_{3}$ nanoparticles were studied by XRD, SEM and UV-Vis spectroscopy. Further the antibacterial activity of the prepared $\mathrm{Fe}_{2} \mathrm{O}_{3}$ nanoparticles was studied against gram - negative bacteria (Salmonella and Escherichia coli) and gram - positive bacteria (Bacillus subtili and Staphylococcus aureus) by disc diffusion method.

$\mathrm{X}$-ray diffraction analysis reveals that the prepared nanoparticles have hexagonal wurtzite structure with preferential orientation along (1 $\left.04 \begin{array}{ll}1 & 4\end{array}\right)$ plane. The crystalline size of the synthesized $\mathrm{Fe}_{2} \mathrm{O}_{3}$ nanoparticles is $12.324 \mathrm{~nm}$. SEM analysis shows that iron oxide nanoparticles have pebble shape. EDX result confirms the presence of $\mathrm{Fe}$ and $\mathrm{O}$ in the prepared $\mathrm{Fe}_{2} \mathrm{O}_{3}$ nanoparticle samples. The band gap value of biosynthesized $\mathrm{Fe}_{2} \mathrm{O}_{3}$ nanoparticles is $2.57 \mathrm{eV}$. Antibacterial studies reveal that the ferric oxide nanoparticles display significant inhibition activities against all tested pathogens.
\end{abstract}

\section{Keywords: $\mathrm{Fe}_{2} \mathrm{O}_{3}$ nanoparticles, Cissus Quadrangularis, Antibacterial activity}

\section{Introduction}

Green chemistry synthesis methods for nanoparticles are advantageous than chemical methods as they are eco-friendly and cost-effective [1]. Researchers investigated the constituents of various herbs, spices and plants. They reported compounds such as amino acids, polyphenols, nitrogenous bases and reducing sugars that act as powerful antioxidants 
[2]. These compounds act as capping and reducing agents for the synthesis of nanoparticles [3]. Plant diversity allows to control the morphology and the size of the nanoparticles [4]. Biomolecules present in plant extracts can be used to reduce metal ions to nanoparticles in a single-step green synthesis process [5]. The metal and metal oxide nanoparticles produced from a plant extract are usually stable even after a month and do not show any visible changes [6]. The iron oxide nanoparticles $\left(\mathrm{Fe}_{2} \mathrm{O}_{3} \mathrm{NPs}\right)$ are widely used since iron is nontoxic, abundant, easy to produce, eco-friendly and cheap. In Ayurvedic medicine, the Cissus quadrangularis (C. quadrangularis) plant treats a variety of ailments such as reducing joint pain and preventing metabolic syndrome. Ayurveda is an Indian traditional health care system based on ancient writings that rely on a natural and holistic approach to physical and mental health.

\section{Materials and Methods}

\subsection{Chemicals, Solvents and Starting Materials}

Cissus quadrangularis plant extract was used as a solvent. Ferric chloride was used as the precursor for $\mathrm{Fe}_{2} \mathrm{O}_{3}$. Sodium hydroxide was used as a stabilizing agent.

\subsection{Precipitation Method}

$\mathrm{Fe}_{2} \mathrm{O}_{3}$ nanoparticles were synthesized by precipitation method. Precipitation is the process of conversion of a solution into solid by converting the substance into insoluble form or by making the solution a super saturated one.

\subsection{Collection of Sample}

Fresh stems of Cissus quandrangularis were collected from the area of V.V.Vanniaperumal College for Women, Virudhunagar. Stems were washed thoroughly by distilled water and were allowed to dry in air at room temperature.

\subsection{Preparation of Leaf Extract}
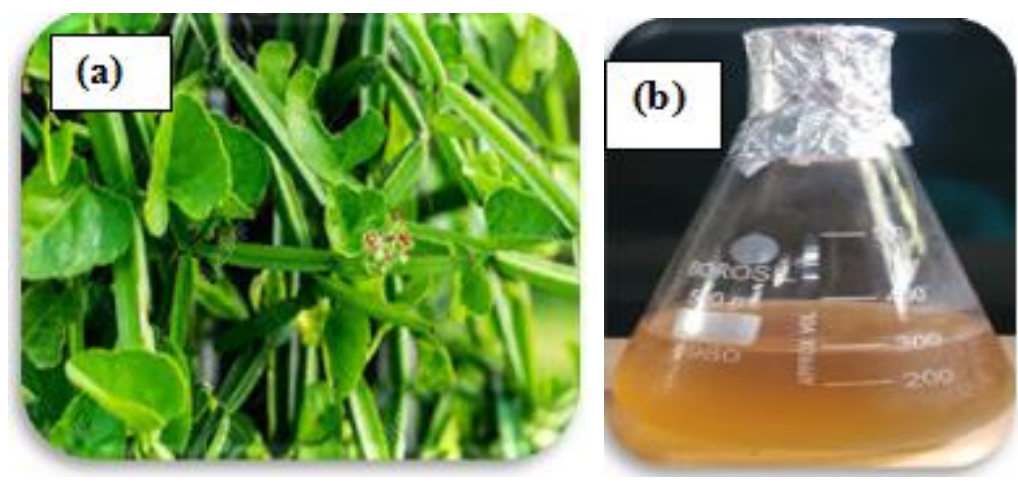

Fig .1: (a) C. quadrangularis plant (b) C. quadrangularis plant extract

The dried Cissus quadrangularis (C. quadrangularis) stems were grinded and the powder was obtained. 15 gram of the powder was mixed in $250 \mathrm{ml}$ distilled water and it was 
heated at $80^{\circ} \mathrm{C}$ for 1 hour and the obtained solution was allowed to cool. Then the extract was filtered with whatman 41 filter paper. The filtrate was stored in a cool and dry place. Figure 1 (a) \& (b) shows the C. quadrangularis plant and extract of $C$. quadrangularis stems.

\subsection{Synthesis of $\mathrm{Fe}_{2} \mathrm{O}_{3}$ Nanoparticles}

$50 \mathrm{ml}$ of plant extract was taken and stirred for 15 minutes. Then 5 gram of ferric chloride was added and stirred for 15 minutes. Then $5 \mathrm{ml}$ of sodium hydroxide was added in drops and whole solution was stirred for 1 hour. The preparation was left undisturbed for 1 day and the precipitates that settled down were collected by precipitation method. The precipitate was preannealed at $100^{\circ} \mathrm{C}$ for 1 hour and post annealed at $300^{\circ} \mathrm{C}$ for 3 hours. Thus the required $\mathrm{Fe}_{2} \mathrm{O}_{3}$ nanoparticles were obtained. The prepared $\mathrm{Fe}_{2} \mathrm{O}_{3}$ nanoparticles were structurally and optically characterized.

\subsection{Microorganisms for Antibacterial Activity}

Ferric oxide nanoparticles synthesized using aqueous stem extract of C. quadrangularis was tested for its potential antibacterial activity against few phyto pathogens. The antibacterial potential of ferric oxide nanoparticles was examined with gram negative bacteria (Salmonella, Escherichia coli) and gram - positive bacteria (Bacillus subtilis, and Staphylococcus aureus). For the investigation of antibacterial potential of synthesized $\mathrm{Fe}_{2} \mathrm{O}_{3}$ nanoparticles, the Muller Hinton agar was formulated. The various concentrations of $\mathrm{Fe}_{2} \mathrm{O}_{3}$ nano particles $(50,100,150$, and $200 \mu \mathrm{g})$ were prepared separately and located on each petriplates and established the control and standard (Ampicillin, Streptomycin, Gentamycin and Chloramphenicol $30 \mu \mathrm{g}$ ) for bacterial discs.

\subsection{Characterization of $\mathrm{Fe}_{2} \mathrm{O}_{3}$ Nanoparticles}

The synthesized $\mathrm{Fe}_{2} \mathrm{O}_{3}$ nanoparticles were structurally and optically analysed. X-ray diffraction (XRD) analysis of $\mathrm{Fe}_{2} \mathrm{O}_{3}$ nanoparticles was performed using X'PERT PRO $\mathrm{X}$ - ray diffractometer. The surface morphology of the prepared nanoparticles was recorded using VEGA3 TESCAN scanning electron microscope. The elemental analysis of nanoparticles was analysed using Bruker EDAX spectrometer. UV-Visible absorption spectra of nanoparticles were recorded using SHIMADIV-1800UV-Vis NIR spectrometer.

\section{Results and Discussions}

\subsection{X-Ray Diffraction Analysis}

The X-ray diffraction pattern of $\mathrm{Fe}_{2} \mathrm{O}_{3}$ nanoparticles synthesized from C. quadrangularis stems extract is shown in Figure 2. 


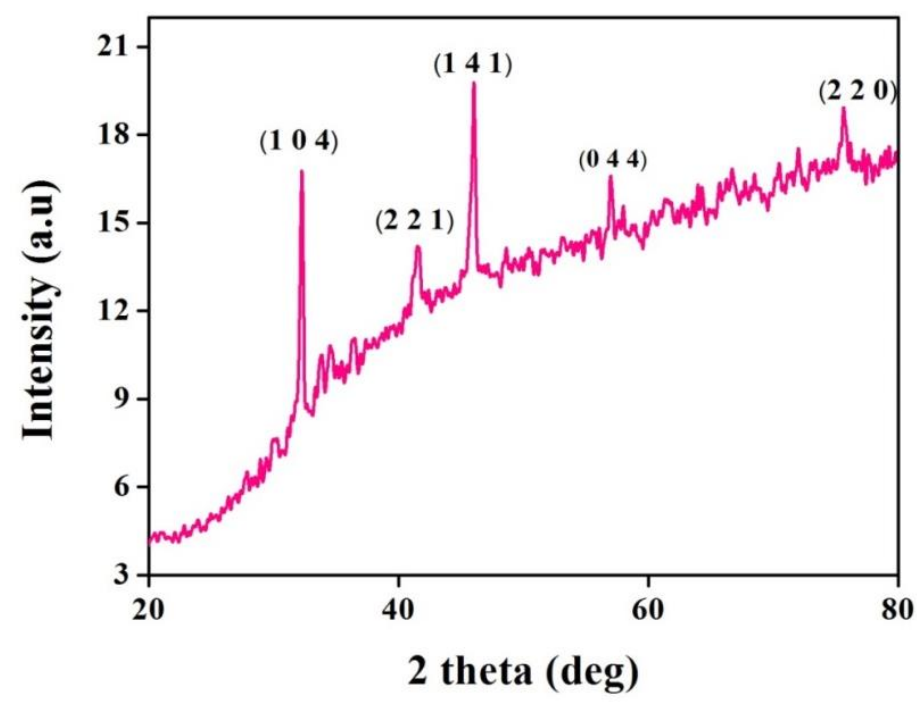

Fig. 2: X-ray diffraction pattern $\mathrm{Fe}_{2} \mathrm{O}_{3}$ nanoparticle prepared from C. quadrangularis stems extract

The prominent peak at $32.834^{\circ}\left(\begin{array}{lll}1 & 0 & 4\end{array}\right)$ was perfectly indexed to the rhombohedral structure which is in agreement with the JCPDS file no.88-2359. The crystalline size (D) of the prepared nano particle was calculated by using Debye Scherer's equation

$$
D=\frac{K \lambda}{\beta \cos \theta}(\mathrm{nm}) \text {----- (1) }
$$

Where,

$\lambda$ is the wavelength of $\mathrm{X}$-ray used, $\beta$ is the full width at half maximum and $\theta$ is the angle of diffraction. The crystallite size of the nano particle was measured as $12.92 \mathrm{~nm}$.

The dislocation density $(\delta)$ defined as the number of dislocation lines per unit volume was estimated using the formula

$$
\delta=\frac{1}{D^{2}} \text { lines } / \mathrm{m}^{2}
$$

The dislocation density calculated for the prepared nano particle was $5.987 \times 10^{14}$ lines $/ \mathrm{m}^{2}$. The strain for the prepared $\mathrm{Fe}_{2} \mathrm{O}_{3}$ nanoparticles was evaluated using the following relation and it was $0.1612 \times 10^{-4}$.

$$
\varepsilon=\frac{\beta \cos \theta}{4}
$$

Thus it is concluded that, $\mathrm{Fe}_{2} \mathrm{O}_{3}$ nanoparticles have better crystalline quality.

\subsection{Scanning electron microscope with elemental analysis}

Figure 3 shows the SEM image of $\mathrm{Fe}_{2} \mathrm{O}_{3}$ nanoparticles. The SEM image examines the nature of morphology of iron oxide nanoparticles and it is found that the particles have pebble like structures. 


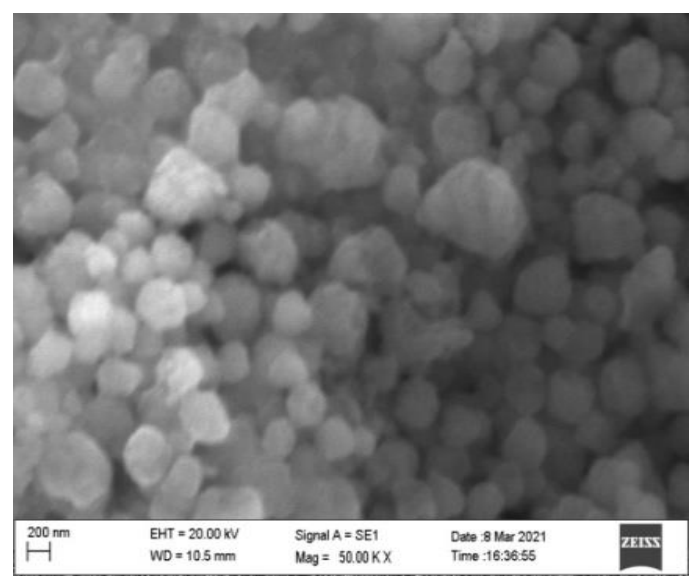

Fig. 3: SEM image of $\mathrm{Fe}_{2} \mathrm{O}_{3}$ nanoparticle

EDX is a chemical micro analysis technique used in conjunction with scanning electron microscopy. Figure 4 shows the spectrum of $\mathrm{Fe}_{2} \mathrm{O}_{3}$ nanoparticles. The spectrum confirmed the presence of $\mathrm{Fe}$ and $\mathrm{O}$.

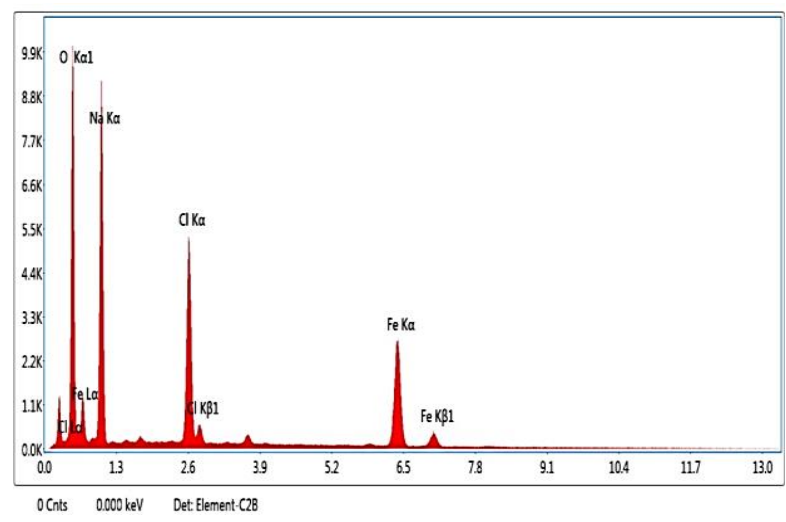

Fig. 4: EDAX spectra of $\mathrm{Fe}_{2} \mathrm{O}_{3}$ nanoparticle

\subsection{UV-Visible Spectral Analysis}

The optical energy band gap of the sample can be calculated from Tauc's relation given by,

$$
\alpha h \vartheta=B\left(h \vartheta-E_{g}\right)^{r---(4)}
$$

where, $\mathrm{r}$ is the index, which depends on mechanism of inter band transitions. It takes values such as $1 / 2$ for direct allowed transitions, 3/2 for direct forbidden transitions, 2 for indirect allowed transitions, 3 for indirect forbidden transitions. B is a constant called band tailing parameter, $\mathrm{h} \vartheta$ is the incident photon energy in $\mathrm{eV}$ and $E_{g}$ is the optical band gap energy.

The optical band gap of the particles was determined using the Tauc's plot. Figure 5 shows the Tauc's plot for ferric oxide nanoparticles prepared from $C$. quadrangularis extract. The band gap value of bulk ferric chloride nanoparticle is found to be equal to $2.70 \mathrm{eV}$. The band gap value for $\mathrm{Fe}_{2} \mathrm{O}_{3}$ nanoparticles synthesized using green solvent (pirandai stem) was $2.52 \mathrm{eV}$. 


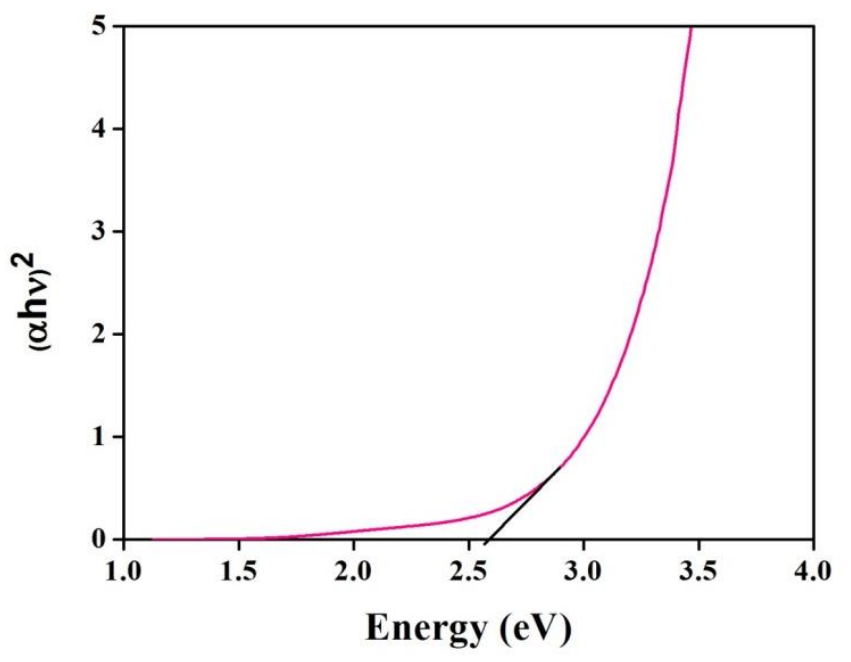

Fig. 5: Tauc's plot for $\mathrm{Fe}_{2} \mathrm{O}_{3}$ nanoparticle synthesized using

\section{C. quadrangularis stem extract}

The bandgap value for $\mathrm{Fe}_{2} \mathrm{O}_{3}$ nanoparticles synthesized using green solvent (C. quadrangularis extract) was lower than bulk value. So it is appropriate for photocatalytic and antibacterial applications.

\section{Antibacterial Analysis}

Ferric oxide nanoparticles find their applications in several biomedical fields such as biomedicine, drug delivery and antiangiogenics [7]. After characterization by different techniques, the synthesized nanoparticles were tested for antibacterial activities. The antibacterial activities of nanoparticles were investigated against four human pathogens, namely Escherichia coli, Staphylococcus aurous, Salmonella and Bacillus subtilus by disc diffusion method (Figure $6 \&$ Table 1).

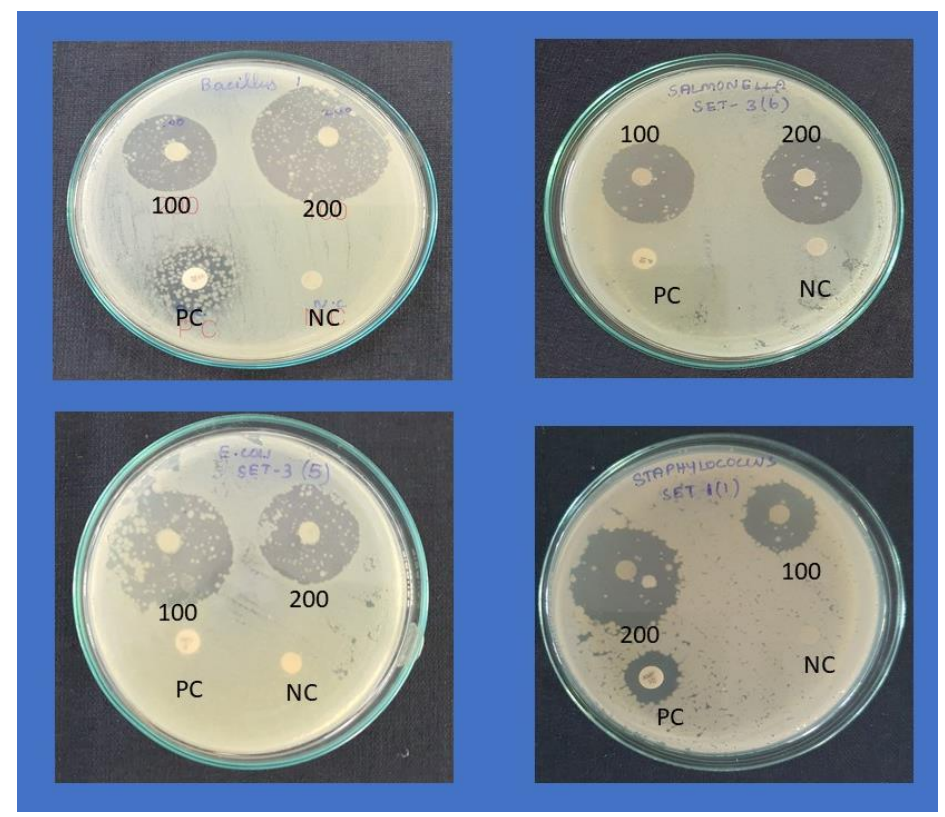

Fig. 6: Antibacterial activity of synthesized $\mathrm{Fe}_{2} \mathrm{O}_{3}$ nanoparticles 
Results revealed that the ferric oxide nanoparticles displayed significant inhibition activities against all the tested pathogens. The highest value was recorded against $S$. aureus $(36 \pm 0.27 \mathrm{~mm}$ inhibition zone) and the lowest value was recorded against E. coli $(23 \pm 0.18$ mm inhibition zone).

Table 1: Antibacterial activity of synthesized $\mathrm{Fe}_{2} \mathrm{O}_{3}$ nanoparticles against pathogens

\begin{tabular}{|l|l|l|l|l|l|c|}
\hline \multirow{2}{*}{ Organism } & \multicolumn{4}{|c|}{ Zone of Inhibition (in mm) } & Antibiotics & $\begin{array}{c}\text { Zone of Inhibition } \\
\text { (in mm) }\end{array}$ \\
\cline { 2 - 5 } & $\mathbf{5 0}$ & $\mathbf{1 0 0}$ & $\mathbf{1 5 0}$ & $\mathbf{2 0 0}$ & & - \\
\hline Escherichia coli sp. & 07 & 16 & 19 & 23 & Ampicillin & 15 \\
\hline Bacillus sp. & 15 & 23 & 29 & 33 & Gentamycin & - \\
\hline Salmonella sp. & 09 & 17 & 19 & 26 & Streptomycin & 10 \\
\hline Staphylococcus sp. & 13 & 24 & 31 & 36 & chloramphenicol & 10 \\
\hline
\end{tabular}

The comparative efficacy of synthesized $\mathrm{ZnO}$ nanoparticles against pathogens was shown in Figure 7. From the Figure, we concluded that, the bacterial growth is inversely proportional to the concentration of nanoparticles.

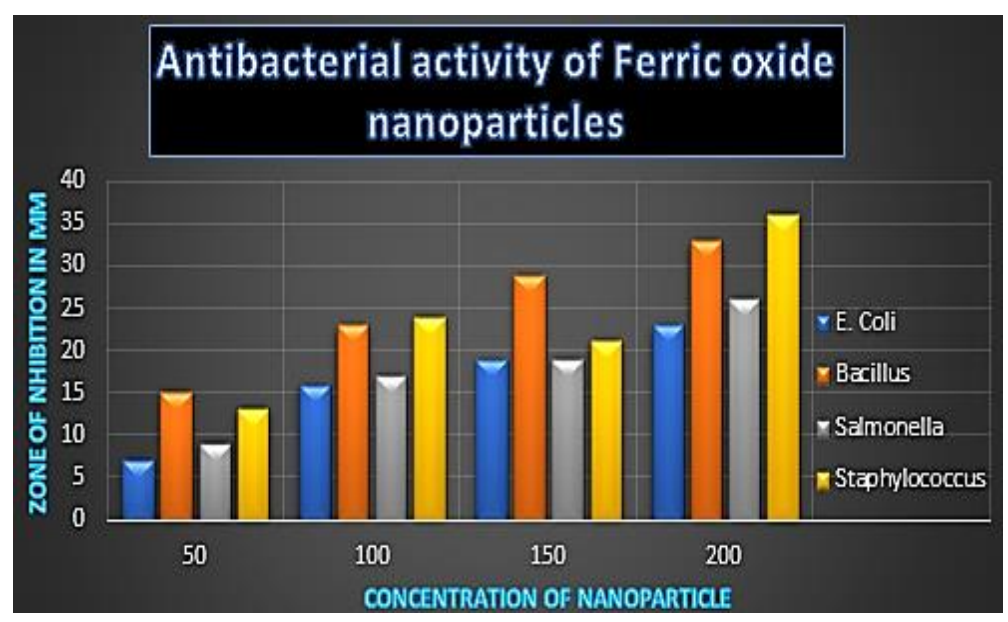

Fig. 7: Comparative efficacy of synthesized $\mathrm{ZnO}$ nanoparticles against pathogens

\section{Conclusion}

$\mathrm{Fe}_{2} \mathrm{O}_{3}$ nanoparticles were successfully synthesized by precipitation method using C. quadrangularis stems extract. The crystalline size of $\mathrm{Fe}_{2} \mathrm{O}_{3}$ nanoparticles synthesized from C. quadrangularis extract is $12.324 \mathrm{~nm}$. From the SEM image, it is found that iron oxide nanoparticles have pebble shape. The band gap value of the synthesized nanoparticle is $2.52 \mathrm{eV}$. The EDX result shows the presence of $\mathrm{Fe}$ and $\mathrm{O}$ in the samples. Antibacterial studies revealed that the ferric oxide nanoparticles display significant inhibition activities against all the tested pathogens. The highest value is recorded against $S$. aureus $(36 \pm 0.27$ $\mathrm{mm}$ inhibition zone) and the lowest value is recorded against E. coli $(23 \pm 0.18 \mathrm{~mm}$ inhibition zone). 


\section{Ethical Approval}

This article does not contain any studies with human participants or animals performed by any of the author.

\section{Consent to participate}

There are no human subjects in this experimental work and hence informed consent is not applicable.

\section{Consent to publish}

Open access: This article is distributed under the terms of Ceative Commons Attribution 4.0 International License which permits unrestricted use, distribution and reproduction in any medium provided appropriate credit is given to the original authors and the source.

\section{Authors Contribution}

Both authors made substantial contributions to conception of design, analysis and critical review of manuscript. Sankareswari carried out the design of study, synthesized the compound and characterization analysis. Indira carried out antibacterial analysis.

\section{Funding}

This research work was not financially supported by any agency or organization.

\section{Competing Interest}

The authors declare that they have no competing interest.

\section{Availability of data and materials}

All information regarding the synthesis and characterization are available with the authors. If necessary, the complete data will be shared with the journal review team.

\section{References}

1. Senapati, S., Ahmad, A., Khan, M. I., Sastry, M., \& Kumar, R. (2005). Extracellular biosynthesis of bimetallic Au-Ag alloy nanoparticles. Small, 1, 517-520.

2. Karkuzhali and Yogamoorthi, (2015). Biosynthesis Of Iron Oxide Nanoparticles Using Aquous Extract of Jatropha Gosspifolia As Source Of Reducing Agent, International Journal of NanoScience and Nanotechnology, 6, 647-55.

3. Parth Malik, Ravi Shankar, Vibhuti Malik, Nitin Sharma, and Tapan Kumar Mukherjee (2014). Green chemistry based benign routes for nanoparticle synthesis. Journal of Nanoparticles, 302429, 1 - 14. 
4. Pradhipa S, Priya R Iyer, (2019). Green Synthesis of Iron Nanoparticles from Moringa Oleifera Seeds, International Journal of Science and Research (IJSR), 8, 2319-7064.

5. Ranjith.S, Kandasamy Arungandhi, Sunmathi.D, Priyanga.S and Monisha.S (2018). Green synthesis of iron nanoparticles from cassia fistula linn leaf extract and its antibacterial activity, European Journal of Biomedical AND Pharmaceutical sciences, 5(6) 490-495.

6. Haung L, Weng X, Chen Z, Megharaj M \& Naidu R. (2014). Synthesis of iron-based nanoparticles using oolong tea extract for the degradation of malachite green. Spectrochimica Acta Part A: Molecular and Biomolecular Spectroscopy, 117, 801804.

7. Yardily.A and Sunitha.N, (2019). Green Synthesis of Iron Nanoparticles using Hibiscus Leaf Extract, Characterization, antimicrobial activity, International Journal of Scientific Research and Review, 8, 32-46. 